\section{Enhanced Celery Germination at Stress Temperature via Solid Matrix Priming}

\author{
Carlos A. Parera, Ping Qiao, and Daniel J. Cantliffe \\ Vegetable Crops Department, Institute of Food and Agricultural Science, \\ University of Florida, Gainesville, FL 32611
}

Additional index words. Apium graveolens, seed disinfection, high temperature, sodium hypochlorite

\begin{abstract}
To alleviate high-temperature-induced reductions in seed germination, emergence, and seedling uniformity in celery (Apium graveolens L.), seeds were primed via solid matrix priming (SMP); $0.5 \mathrm{~g}$ celery seeds was incubated at $15 \mathrm{C}$ with $10 \mathrm{~g}$ calcined clay and $2 \mathrm{ml}$ water. After 2 days, 1, 2, 3, or $4 \mathrm{ml}$ water or $1 \% \mathrm{NaOCl}$ solution was added and seeds were kept for $2,4,6,8,10,12$, and 14 additional days. The germination percentage and coefficient of germination velocity (COV) were calculated for each treatment at 15 and 30C. The seeds primed with $\mathrm{NaOCl}$ gained significantly less moisture after 8 days of priming than those treated with water, regardless of the volume added. Germination of nonprimed seeds was $83 \%$ and $2 \%$ at 15 and $30 \mathrm{C}$, respectively. Final germination at $30 \mathrm{C}$ increased to $>80 \%$ when seeds were primed with 3 or $4 \mathrm{ml} \mathrm{NaOCl}$ solution or $3 \mathrm{ml}$ water for $>10$ days. SMP treatment significantly reduced the negative effect of high temperature on celery seed germination.
\end{abstract}

Poor germination, emergence, and seedling uniformity are common in celery cultivars sown at temperatures $>18$ to $20 \mathrm{C}$ (Brocklehurst et al., 1983; Tanne and Cantliffe, 1989). The detrimental effects of high temperature on celery germination have been studied extensively (Thomas et al., 1975). Many presowing seed treatments to improve celery germination and seedling uniformity have been suggested. Thomas (1983) reported higher germination percentage and faster germination when celery seeds were soaked in a combined solution of gibberellin $\left(\mathrm{A}_{4} / \mathrm{A}_{7}\right)$ and (2-chloroethyl)phosphonic acid (ethephon) at low temperature. The combination of seed priming and growth regulators resulted in an improved germination rate and total germination of celery (Brocklehurst et al., 1983; Tanne and Cantliffe, 1989). However, these treatments had little effect on the rate and total germination at temperatures $>25 \mathrm{C}$.

Solidmatrix priming (SMP) is a presowing technique that uses a solid as an osmoticum. This technique has been used to improve seed germination and rate in many species (Kubik et al., 1988; Parera and Cantliffe, 1990, Taylor et al. 1988). Sodium hypochlorite has been reported as an effective seed disinfectant (Elmer and Stephens, 1988; Fieldhouse and Sasser, 1975). Taylor (1949) combined water soaking and $\mathrm{NaOCl}$ addition to increase germination rate in celery. Lettuce (Lactuca sativa L.) seed them-to-inhibition was diminished by $\mathrm{NaOCl}$ addition (Drew and Brocklehurst, 1984). Parera

Received for publication $10 \mathrm{Feb}$. 1992. Acceptedfor publication 3 Sept. 1992. Univ. of Florida, Agricultural Experimental Station Journal Series no. R02004. The cost of publishing this paper was defrayed in part by the payment of page charges. Under postal regulations, this paper must therefore be hereby marked advertisement solely to indicate this fact.
Table 1. Analysis of variance mean squares for moisture content in celery seeds during priming.

\begin{tabular}{lrrr}
\hline & \multicolumn{3}{c}{ Seed moisture } \\
\cline { 2 - 4 } Source & df & Mean square & \multicolumn{1}{c}{$\mathbf{F}$} \\
\hline Time $(\mathrm{T})^{2}$ & 7 & 4,855 & $40^{* *}$ \\
Rep/T (Error a) & 24 & 121 & \\
Milliliter (M) & 3 & 21,663 & $1,155^{* *}$ \\
Solution (S) & 1 & 2,241 & $119^{* *}$ \\
$\mathrm{~T} \times \mathrm{M}$ & 21 & 1,099 & $59^{* *}$ \\
$\mathrm{~T} \times \mathrm{S}$ & 7 & 86 & $5^{* *}$ \\
$\mathrm{M} \times \mathrm{S}$ & 3 & 904 & $48^{* *}$ \\
$\mathrm{~T} \times \mathrm{M} \times \mathrm{S}$ & 21 & 66 & $4^{* *}$ \\
Error b & 168 & 19 & \\
cv $(\%)$ & 12.6 & & \\
\hline
\end{tabular}

${ }^{2}$ Days of priming.

Milliliters of water or $1 \% \mathrm{NaOCl}$ solution.

${ }^{x}$ Water or $1 \% \mathrm{NaOCl}$ solution.

** Significant at $P=0.01$.

in darkness. The SMP treatment consisted of placing $0.5 \mathrm{~g}$ seeds $(\approx 1000$ seeds $), 10 \mathrm{~g}$ calcined clay (Emathlite, Mid-Florida Mining, Lowell, Fla.), and $2 \mathrm{ml}$ distilled water in a 250$\mathrm{ml}$ container (Filtunit, Nalgene, Rochester, N.Y.) (Parera and Cantliffe, 1991). The containers were incubated at $15 \mathrm{C}$ in light $(15$ $\left.\mu \mathrm{mol} \cdot \mathrm{s}^{-1} \cdot \mathrm{m}^{-2}\right)$ under continuous rotation $(0.22$ $\mathrm{rpm}$ ) in a rotator (Lab-Line Instruments, Melrose Park, Ill.). After 2 days of incubation, $1,2,3$, or $4 \mathrm{ml}$ distilled water or $\mathrm{NaOCl}$ solution $(1 \%, \mathrm{v} / \mathrm{v})$ was added to each container. Priming continued for an additional 2, 4, 6, 8, 10,12 , or 14 days under the same conditions. Moisture content of seeds was measured at each priming time and for each solution amount and treatment. A 25-seed sample was dried at $85 \mathrm{C}$ for $48 \mathrm{~h}$ and moisture content was expressed on a dry-weight basis.

After each treatment, the seeds were dried at $15 \mathrm{C}$ and $20 \% \mathrm{RH}$ to a $4.7 \%$ moisture content and stored no longer than 1 month as noted above. Four replications of 25 nonprimed or

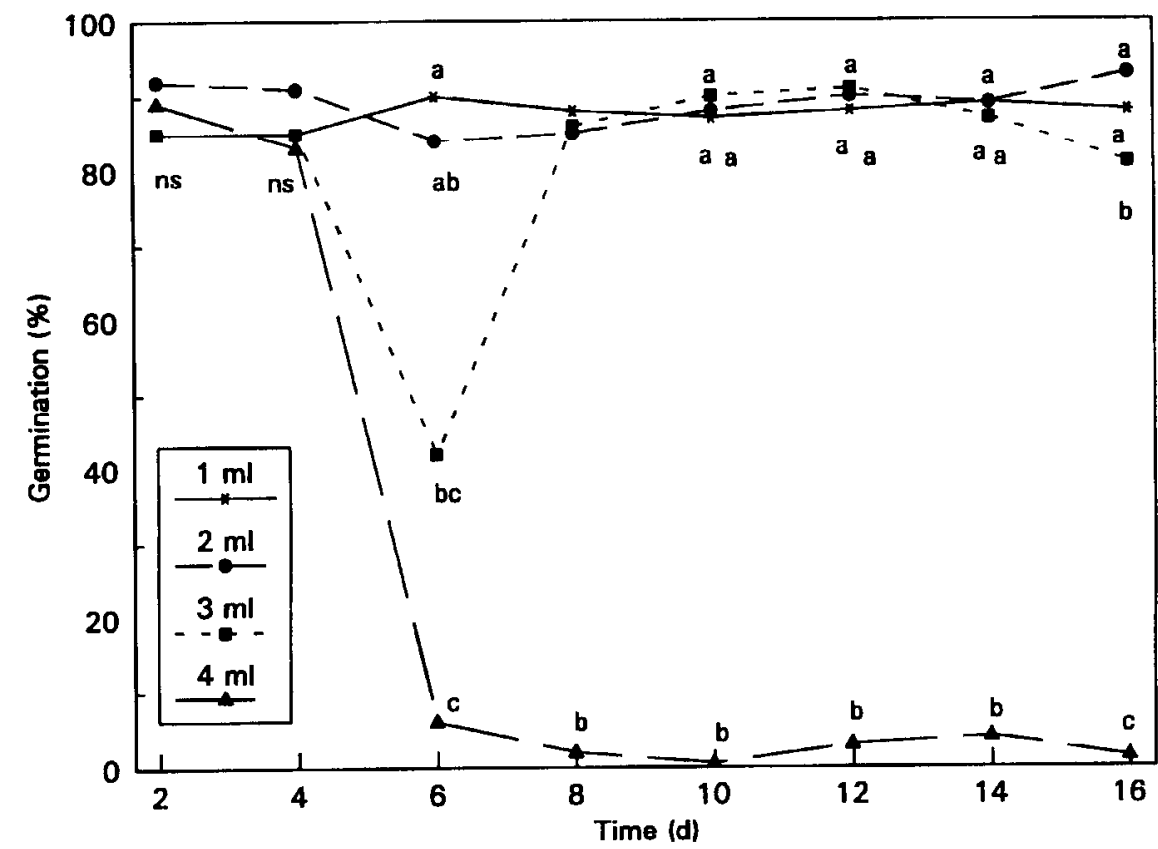

Fig. 1. Final germination percentage of celery seed primed with water via solid matrix priming and germinated at $15 \mathrm{C}$. Mean separation by priming time using Duncan's multiple range test, $P=0.05$; Nontreated seeds germinated, $83 \%$. Water was added at $1,2,3$, or $4 \mathrm{ml}$. 
Table 2. Moisture content of celery seeds during priming when $1,2,3$, or $4 \mathrm{ml}$ water or $1 \% \mathrm{NaOCl}$ solution was added.

\begin{tabular}{|c|c|c|c|c|c|c|}
\hline \multirow[b]{3}{*}{ Solution } & \multirow[b]{3}{*}{ Time $^{y}$} & \multicolumn{4}{|c|}{ Moisture content of seed (\%) } & \\
\hline & & \multicolumn{4}{|c|}{ Milliliter $^{2}$} & \\
\hline & & 1 & 2 & 3 & 4 & LSI \\
\hline $\mathrm{NaOCl}$ & 2 & 19.9 & 19.8 & 20.1 & 19.5 & 2. \\
\hline \multirow[t]{2}{*}{ Water } & & 19.5 & 20.2 & 19.6 & 20.0 & 1.2 \\
\hline & & NS & NS & NS & Ns & \\
\hline $\mathrm{NaOCl}$ & 4 & 23.9 & 22.8 & 59.8 & 87.7 & \\
\hline \multirow[t]{2}{*}{ Water } & & 24.7 & 32.4 & 68.5 & 92.7 & 10. \\
\hline & & NS & NS & NS & NS & \\
\hline $\mathrm{NaOCl}$ & 6 & 21.1 & 26.4 & 48.7 & 86.8 & $f$ \\
\hline \multirow[t]{2}{*}{ Water } & & 22.2 & 27.1 & 57.5 & 96.3 & 3. \\
\hline & & NS & NS & $*$ & $*$ & \\
\hline $\mathrm{NaOCl}$ & 8 & 18.7 & 22.1 & 38.6 & 69.4 & 5 \\
\hline Water & & $\begin{array}{c}20.4 \\
*\end{array}$ & $\begin{array}{l}24.6 \\
* *\end{array}$ & $\begin{array}{c}49.4 \\
*\end{array}$ & $\begin{array}{l}87.7 \\
* *\end{array}$ & \\
\hline $\mathrm{NaOCl}$ & 10 & 17.3 & 21.9 & 26.4 & 50.9 & \\
\hline \multirow[t]{2}{*}{ Water } & & 17.5 & 22.5 & 36.9 & 80.1 & \\
\hline & & NS & NS & $*$ & $* *$ & \\
\hline $\mathrm{NaOCl}$ & 12 & 16.9 & 20.9 & 24.6 & 40.9 & 10 \\
\hline \multirow[t]{2}{*}{ Water } & & 16.3 & 20.6 & 28.2 & 71.1 & \\
\hline & & NS & NS & NS & $*$ & \\
\hline $\mathrm{NaOCl}$ & 14 & 15.6 & 18.0 & 23.1 & 31.8 & \\
\hline \multirow[t]{2}{*}{ Water } & & 15.3 & 19.5 & 26.9 & 56.8 & \\
\hline & & NS & NS & NS & $*$ & \\
\hline $\mathrm{NaOCl}$ & 16 & 13.8 & 17.9 & 20.5 & 22.8 & 3 \\
\hline \multirow[t]{2}{*}{ Water } & & 13.9 & 17.6 & 24.5 & 36.6 & 4 \\
\hline & & NS & NS & NS & $* *$ & \\
\hline
\end{tabular}

${ }^{2}$ Milliliters of water or $1 \% \mathrm{NaOCl}$ solution added 2 days after priming.

${ }^{\mathrm{y}}$ Days of priming.

Ns. *, ${ }^{* *}$ Nonsignificant or significant at $P=0.5$ or 0.01 , respectively.

primed seeds were germinated in 5-cm petri dishes on two layers of Whatman no. 1 filter paper soaked with $1.5 \mathrm{ml}$ distilled water, then placed in incubators set at 15 or $30 \mathrm{C}$ with 23 umol $\cdot \mathrm{s}^{-1} \cdot \mathrm{m}^{-2}$ light. Germination was recorded daily and counted when the radicle became visible. Percentage of germination and coefficient of germination velocity $(\mathrm{COV})(\mathrm{Scott}$ et al., 1984) were calculated. The experiments were conducted as a randomized completeblock design with four replications. The data were subjected to analysis of variance on a split-block experimental design, with priming time as a main block. Percentage data were arcsin-transformed before analysis of variance was conducted.

Since there were significant interactions among solution type, time, and quantity (Table $1)$, the main effects for moisture content were analyzed separately. Seeds primed with 1 or 2 $\mathrm{ml}$ of water had significantly more moisture after 8 days of priming than seeds primed with $1 \% \mathrm{NaOCl}$ solution (Table 2). The seeds primed with $3 \mathrm{ml} \mathrm{NaOCl}$ for 6 to 10 days and those primed with $4 \mathrm{ml} \mathrm{NaOCl}$ for 6 to 16 days gained less moisture than seeds primed with water. After 14 days of priming, the seeds primed with $4 \mathrm{ml}$ water contained almost twice as much moisture as seeds primed with the same volume of $1 \% \mathrm{NaOCl}$ solution. The lower osmotic potential of the $\mathrm{NaOCl}$ solution $(-1.28 \mathrm{MPa})$ compared with the water's $(-0.02 \mathrm{MPa})$ could explain the differences observed between the treatments. The moisture content of the seeds rapidly increased during the fist 4 days of priming, then gradually decreased to $20 \%$ to $30 \%$ at 16 days of priming.

At both germination temperatures, the in-
$(90 \%)$ in the seeds], precocious seed germination in the container during priming, or both may have contributed to the lower germination rate observed. Although adding $4 \mathrm{ml}$ $\mathrm{NaOCl}$ led to relatively high seed moisture content, $\mathrm{NaOCl}$ would be expected to prevent fungal growth.

At 30C, 4 or 6 days of priming with 3 and $4 \mathrm{ml} \mathrm{NaOCl}$, respectively, or 8 days with $3 \mathrm{ml}$ water significantly increased final germination percentage (Fig. 2) and COV (data not shown). The highest germination percentage $(>80 \%)$ was reached at $30 \mathrm{C}$ when 3 or $4 \mathrm{ml}$ of $\mathrm{NaOCl}$ solution and 8 to 16 days of incubation were used. When water was used instead of $\mathrm{NaOCl}$ solution, the combination of $3 \mathrm{ml}$ water and 10 to 16 days incubation (Fig. 2) gave the highest final germination percentage. Similar to the experiment at $15 \mathrm{C}, 4 \mathrm{ml}$ water did not improve germination at $30 \mathrm{C}$. The moisture content of the seeds when 1 or $2 \mathrm{ml}$ of water or $\mathrm{NaOCl}$ was used might not have been enough to start or continue the priming (germination) process; thus, no effect on germination was observed at $30 \mathrm{C}$ at these two moisture levels.

Before radicle protrusion, the celery embryo must at least double its size. The embryo of primed celery seeds has been shown to increase to almost twice its size after priming with osmotic solutions (Karssen et al., 1989). Sodium hypochlorite reduced thermo-inhibition in lettuce seeds by weakening the pericarp (Drew and Blocklehurst, 1984). The most effective treatments when the seeds were germinated at high temperature (30C) were 1) SMP priming for 10 to 16 days with 3 or $4 \mathrm{ml} 1 \%$ $\mathrm{NaOCl}$ solution, and 2) SMP priming with 3 $\mathrm{ml}$ water. The combination of embryo growth during SMP and pericarp weakening by a long incubation period, $\mathrm{NaOCl}$ addition, or both may have increased total germination and germination rate of celery at high temperature after SMP treatment.

\section{Literature Cited}

Brocklehurst, P.A., W.E. Rankin, and T.H. Thomas. 1983. Stimulation of celery seed germination and seedling growth with combined ethephon, gibberellin and polyethylene glycol seed treatments. Plant Growth Regulat. 1:195-202.

Drew, R.L. and P.A. Brocklehurst. 1984. Investiga-

Table 3. Analysis of variance mean squares for germination percentage at 30 and $15 \mathrm{C}$ in celery seeds after priming.

\begin{tabular}{|c|c|c|c|c|c|}
\hline \multirow[b]{3}{*}{ Source } & \multirow[b]{3}{*}{ df } & \multicolumn{4}{|c|}{ Temp } \\
\hline & & \multicolumn{2}{|c|}{$30 \mathrm{C}$} & \multicolumn{2}{|c|}{$15 \mathrm{C}$} \\
\hline & & Mean square & $\mathrm{F}$ & Mean square & $F$ \\
\hline Time $(T)^{z}$ & 7 & 1.0239 & $19^{* *}$ & 0.1668 & $4^{* *}$ \\
\hline Rep/PT (Error a) & 24 & 0.0524 & & 0.0248 & \\
\hline Milliliter $(\mathbf{M})^{y}$ & 3 & 4.4985 & $193^{* *}$ & 2.6463 & $129^{* *}$ \\
\hline Solution $(S)^{x}$ & 1 & 0.8746 & $80^{* *}$ & 3.0387 & $149^{* *}$ \\
\hline $\mathrm{T} \times \mathrm{M}$ & 21 & 0.3118 & $13^{* *}$ & 0.1579 & $8^{* *}$ \\
\hline$T \times S$ & 7 & 0.1003 & $4^{* *}$ & 0.1319 & $7^{* *}$ \\
\hline$M \times S$ & 3 & 0.9088 & $39^{* *}$ & 2.4531 & $120^{* *}$ \\
\hline $\mathrm{T} \times \mathrm{M} \times \mathrm{S}$ & 21 & 0.1225 & $5^{* *}$ & 0.1531 & $8^{* *}$ \\
\hline Error $\mathbf{b}$ & 168 & 0.0232 & & 0.0204 & \\
\hline $\mathrm{CV}(\%)$ & & 39.8 & & 12.8 & \\
\hline
\end{tabular}

${ }^{\overline{2}}$ Days of priming.

${ }^{y}$ Milliliters of water or $1 \% \mathrm{NaOCl}$ solution.

'Water or $1 \% \mathrm{NaOCl}$ solution.

"significant at $P=0.01$. 

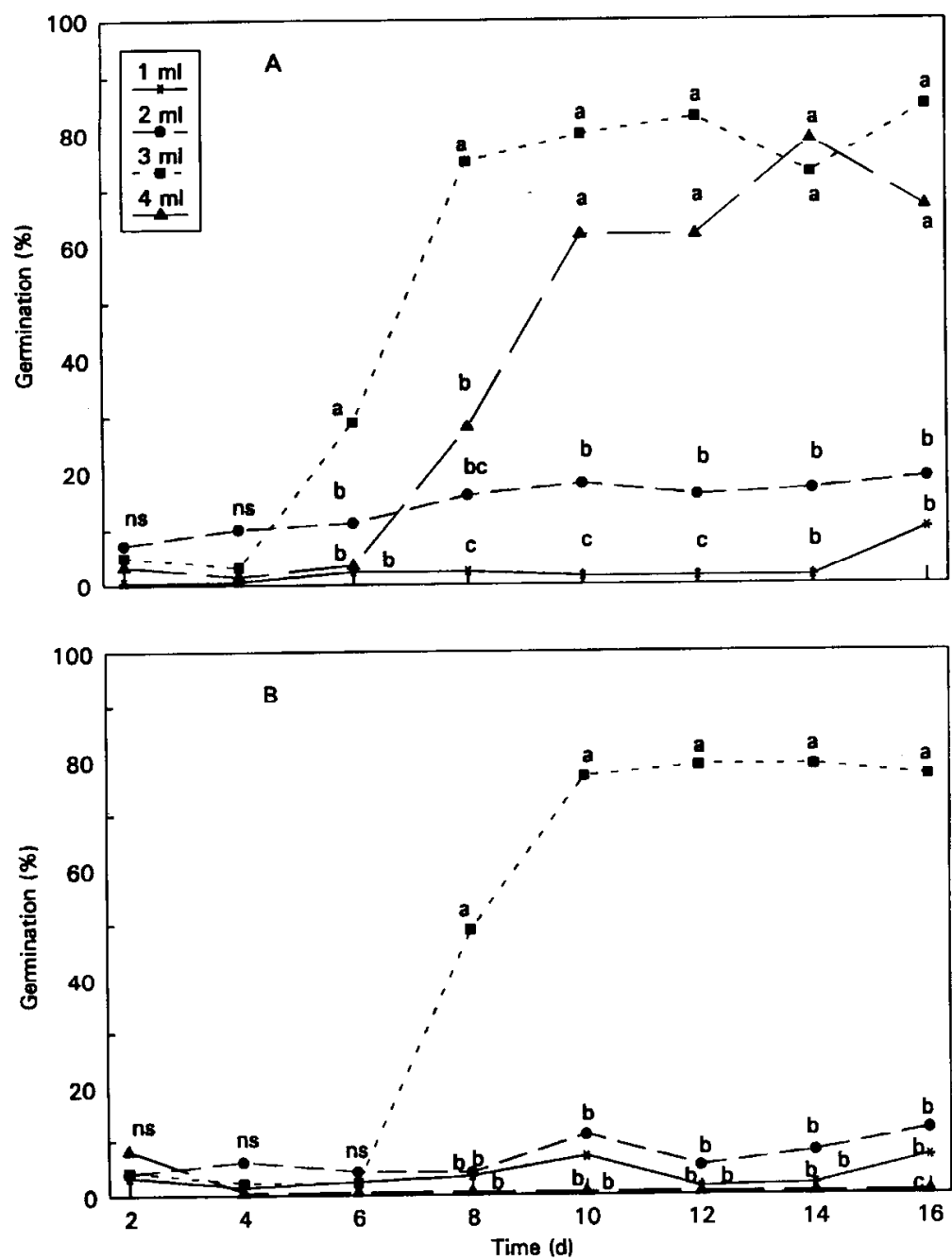

Fig. 2. Final germination percentage of celery seed primed via solid matrix priming using (A) $1 \% \mathrm{NaOCl}$ or (B) water and germinated at 30C. Mean separation by priming time using Duncan's multiple range test, $P=0.05$; Nontreated seeds germinated, $2 \%$.

tions on the control of lettuce seed germination at high temperature. J. Expt. Bot. 35:986-983.

Elmer, W.H. and C.T. Stephens. 1988. Comparison of technique for eliminating contaminants from asparagus seeds. HortScience 23:231-232.

Fieldhouse, D.J. and M. Sasser. 1975. Stimulation of pepper seed germination by sodium hypochlorite. HortScience 10:622.

Karssen, C.M., A. Haigh, P. van der Toorn, and R. Weges. 1989. Physiological mechanisms involved in seed priming, p. 269-280. In: R.B. Taylorson (ed.). Recent advances in the development and germination of seeds. Plenum, New York, N.Y.

Kubik, K.K., J.A. Eastin, J.D. Eastin, and K.M. Eskridge. 1988. Solid matrix priming of tomato and pepper. Proc Intl. Conf. Stand Establishment for Hort. Crops, Lancaster, Pa. p. 86-89.

Parera, CA. and D.J. Cantliffe. 1990. Improved stand establishment of $s h 2$ sweet corn by solid matrix priming and seed disinfection treatments. Proc. Intl. Conf. Stand Establishment for Hort. Crops, St. Paul, Minn. p. 91-98.

Parera, C.A. and D.J. Cantliffe. 1991. Improved germination and modified imbibition of shrunken-2 sweet corn by seed disinfection and solid matrix priming. J. Amer. Soc. Hort. Sci. 117:400-403.

Scott, S.J., R.A. Jones, and W.S. Williams. 1984. Review of data analysis methods for seed germination. Crop Sci. 24:1192-1198.

Tanne, I. and D.J. Cantliffe. 1989. Seed treatments to improve rate and uniformity of celery seed germination. Proc. Fla. State Hort. Soc. 102:319322.

Taylor, A.G., D.E. Klein, and T.H. Whitlow. 1988. SMP: Solid matrix priming of seeds. Scientia Hort. 37:1-11.

Taylor, C.A. 1949. Some factors affecting germination of celery seeds. Plant Physiol. 24:93-102.

Thomas, T.H. 1983. Stimulation of celeriac and celery seed germination by growth regulator seed soaks. Seed Sci. \& Technol. 11:301-305.

Thomas, T.H., D. Palevitch, N.L. Biddington, and R.B. Austin. 1975. Growth regulators and the phytochrome mediated dormancy of celery seeds. Physiol. Plant. 35:101-106. 